\title{
Physical Properties of Gas Hydrate-Bearing Pressure Core Sediments in the South China Sea
}

\author{
Jiangong Wei, ${ }^{1,2}$ Tingting Wu $\mathbb{D},{ }^{1,2}$ Xiuli Feng $\mathbb{D}^{3}{ }^{3}$ Jinqiang Liang, $^{1}$ Wenjing Li, $^{2}$ Rui Xie, ${ }^{2}$ \\ and Gang $\mathbf{W u}^{2}$ \\ ${ }^{1}$ Southern Marine Science and Engineering Guangdong Laboratory (Guangzhou), Guangzhou 511458, China \\ ${ }^{2}$ MLR Key Laboratory of Marine Mineral Resources, Guangzhou Marine Geological Survey, Guangzhou 510075, China \\ ${ }^{3}$ Key Laboratory of Submarine Geosciences and Prospecting Techniques, MOE; College of Marine Geosciences, Ocean University \\ of China, Qingdao 266100, China
}

Correspondence should be addressed to Tingting Wu; wutingtingqd@163.com and Xiuli Feng; fengxiuli@ouc.edu.cn

Received 2 December 2020; Revised 12 January 2021; Accepted 13 April 2021; Published 30 April 2021

Academic Editor: Paolo Madonia

Copyright (C) 2021 Jiangong Wei et al. This is an open access article distributed under the Creative Commons Attribution License, which permits unrestricted use, distribution, and reproduction in any medium, provided the original work is properly cited.

Gas hydrates are a potential future energy resource and are widely distributed in marine sediments and permafrost areas. The physical properties and mechanical behavior of gas hydrate-bearing sediments are of great significance to seafloor stability and platform safety. In 2013, a large number of pressure cores were recovered during China's second gas hydrate drilling expedition in the South China Sea. In this study, we determined the gas hydrate distribution, saturation, physical properties, and mechanical behavior of the gas hydrate-bearing sediments by conducting Multi-Sensor Core Logger measurements and triaxial and permeability tests. Disseminated gas hydrates, gas hydrate veins, and gas hydrate slabs were observed in the sediments. The gas hydrate distribution and saturation are spatially heterogeneous, with gas hydrate saturations of $0 \%-55.3 \%$. The peak deviatoric stress of the gas hydrate-bearing sediments is $0.14-1.62 \mathrm{MPa}$ under a $0.15-2.3 \mathrm{MPa}$ effective confining stress. The permeability is $0.006-0.095 \times 10^{-3} \mu \mathrm{m}^{2}$, and it decreases with increasing gas hydrate saturation and burial depth.

\section{Introduction}

Natural gas hydrates, which are widely distributed in continental margins and permafrost areas, have been suggested to be a potential renewable energy resource in the future. Understanding the physical properties of gas hydratebearing sediments is important for gas hydrate production from marine sediments [1-5]. Depending on the upward methane flux, temperature, pressure, and pore water salinity, the burial depth and distribution of the gas hydrates vary significantly from the seafloor to the depths of several hundred meters below the seafloor [6-9]. Previous lab tests and numerical simulations have revealed that gas hydrate formation and decomposition may change the sediments' properties, such as their permeability and strength [1015]. Strength decreases resulting from gas hydrate dissociation may lead to geohazards, such as continental landslides $[16,17]$ and seafloor subsidence.
Lab experiments are the main method used to determine the physical properties of gas hydrate-bearing sediments, such as their permeability and shear strength. Key parameters, such as the permeability and shear strength, needed for numerical simulations can be obtained through lab experiments and field testing [18]. The gas hydrates used for lab experiment are either synthetic [19-21] or natural samples [22-24]. In order to prevent gas hydrates from dissociating during core retrieval from marine sediments [23, $25,26]$, various pressure coring tools have been developed in recent years [3, 27-29]; however, only a few studies have been conducted on pressure core gas hydrate-bearing sediments $[22,23,30]$.

Six gas hydrate drilling expeditions [31-37] and two production tests were successfully conducted by the Guangzhou Marine Geological Survey between 2007 and 2019 on the northern continental slope of the South China Sea [38]; however, the geomechanical properties and permeability of the 
gas hydrate-bearing sediments have not been publically reported. In this study, we determined the physical properties of the hydrate-bearing pressure core sediments obtained from the Pearl River Mouth Basin in the South China Sea in 2013. X-ray imaging was conducted and the P-wave velocity and gamma density were measured using a Multi-Sensor Core Logger (MSCL). The gas hydrate saturations were estimated via depressurization. The physical properties of gas hydrate-bearing sediments, including the permeability and strength, were measured using a Pressure Core Analysis and Transfer System (PCATS) developed by the GeoTek Company. By comparing our results with those of previous studies, we investigated the influences of the gas hydrate distribution, saturation, effective confining strength, and burial depth on the permeability and strength of the sediments.

\section{Materials and Methods}

The sediment cores were retrieved using pressure coring tools during the GMGS2 in the Pearl River Mouth Basin on the northern continental slope of the South China Sea (Figure 1). The PCATS has been used for gas hydrate exploration for a long time [22]. It can keep the gas hydratebearing sediments under the original in situ pressure (high pressure) during the entire coring and processing procedure, which enables further onshore analysis of the gas hydrates. By using the PCATS, the in situ pressure was maintained and the cores were transferred from the autoclaves into a logging chamber where the gamma density and $\mathrm{P}$-wave velocity were measured and the X-ray imaging was conducted. Furthermore, using the PCATS, the cores were cut into subsamples under the in situ pressure (Table 1) for further tests, including triaxial and permeability tests. Some subsamples were depressurized to estimate the gas hydrate saturation. The temperature and pressure of the cores were recorded throughout the entire process (Figure 2).

2.1. PCATS MSCL Tests. The gamma density was measured using a 137 Cs source and a sodium iodide detector, with an error of $\pm 2 \%$. The P-wave velocity was measured using the pulse transmission technique at $250 \mathrm{kHz}$, with an error of $\pm 1 \%$. The X-ray images were collected using a microfocus source and an image intensifier with a pixel resolution of 120 microns. The voltage and current of the polychromatic X-ray source were tuned to provide the best quality. All of the datasets were collected at a spacing of $0.5 \mathrm{~cm}$.

\subsection{PCATS Triaxial Strength and Permeability Tests}

2.2.1. Preparation. Based on the MSCL logging data, specific intervals were cut from the cores for the triaxial tests. Subsamples were transferred to a triaxial transfer vessel under in situ pressure and a temperature of $8^{\circ} \mathrm{C}-10^{\circ} \mathrm{C}$ to prevent the gas hydrates from dissociating. The subsamples (length: $115 \mathrm{~mm}$, diameter: $57 \mathrm{~mm}$ ) were transferred to the PCATS triaxial apparatus [22].

Consolidation was followed by the continuous application of effective stresses of up to the calculated in situ values (Table 1). The pore pressure was reduced while maintaining the confining pressure in order to apply an effective stress on the samples. The in situ effective stress was estimated using the logging-while-drilling density log [39]. A positive axial load, which was achieved by incrementally moving the top cap down as the sample consolidated, was also maintained to ensure contact between the top cap and the sample.

2.2.2. Permeability Test. The permeability was measured by subjecting the samples to a hydraulic head and measuring the flow rate through the samples. The head pressure was adjusted to create sufficient flow through the samples on a reasonable time scale to accomplish the permeability measurements (up to 12 hours). The pressure and fluid volume were recorded over time, and based on this, the hydraulic conductivity $(K)$ was calculated and converted to the permeability $(K)$ as follows:

$$
\begin{aligned}
& K=\frac{Q \cdot L}{A \cdot h}, \\
& K=\frac{K \bullet \mu}{\rho \bullet g},
\end{aligned}
$$

where $Q$ is the water flow rate, $A$ is the cross-sectional area, $h$ is the hydraulic head, $L$ is the sample length, $\mu$ is the fluid dynamic viscosity, $\rho$ is the fluid density, and $g$ is the gravitational acceleration. The dynamic viscosity of the water was assumed to be $1.298 \times 10^{-3} \mathrm{~Pa} \bullet$ at $5^{\circ} \mathrm{C}$ [40].

2.2.3. Triaxial Test. Following the permeability test, the undrained triaxial test was performed using a constant axial strain rate $(2 \%$ of the sample's height per hour to record the sample changes). The tests were conducted until the sample failed or the torque limits of the servo drives delivering the load to the samples were reached. The axial load, axial strain, cell pressure, and pore pressure were recorded during the test.

2.3. Depressurization and Gas Hydrate Quantification. The subsamples were depressurized, and all of the released water and gases were collected. During depressurization, the effective confining stresses were greater than the pore pressure in order to avoid fluid leakage. The total gas volume was calculated based on the gases released during the depressurization, which were collected at $8^{\circ} \mathrm{C}$ and atmospheric pressure in a water-filled $2000 \mathrm{~mL}$-measuring cylinder. The temperature and pressure of the sediments measured by the Fugro probes were used to calculate the in situ methane saturation [41]. When the total gas volume was greater than the methane from the saturated pore waters, the extra methane was assumed to be from the methane hydrates.

\section{Results}

Three pressure cores were retrieved from boreholes GMGS205B, GMGS2-08C, and GMGS2-16D. The basic information for the subsamples is presented in Table 1.

3.1. P-T Conditions of the Pressure Cores. The pressure and temperature of the cores were recorded by the sensors in the corer (Figure 2). During the deployment, the temperature 


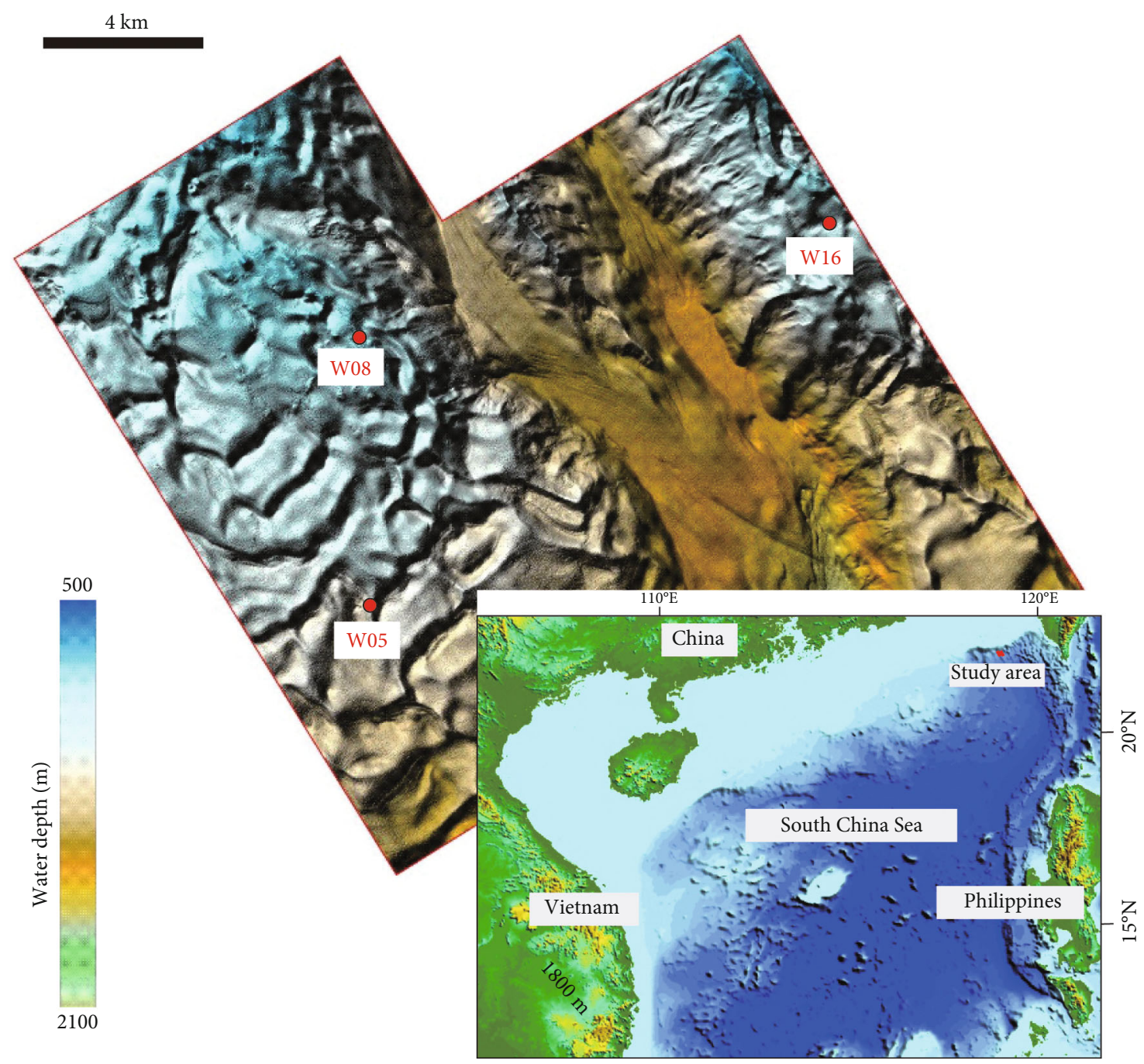

FIgure 1: Topography of the study area and the location of the drilling sites. The inset shows the topography of the South China Sea and the location of the study area.

TABLE 1: Information about the subsamples and test results.

\begin{tabular}{|c|c|c|c|c|c|c|c|c|c|c|}
\hline & $\begin{array}{c}\text { Water } \\
\text { depth }(m)\end{array}$ & $\begin{array}{l}\text { Depth } \\
\text { (mbsf) }\end{array}$ & $\begin{array}{c}\mathrm{Vp} \\
(\mathrm{m} / \mathrm{s})\end{array}$ & $\begin{array}{c}\text { In situ } \\
\text { effective } \\
\text { stress (MPa) }\end{array}$ & $\begin{array}{c}\text { Gamma } \\
\text { density } \\
\left(\mathrm{g} / \mathrm{cm}^{3}\right)\end{array}$ & $\begin{array}{c}\text { GH saturation } \\
(\%)\end{array}$ & $\begin{array}{l}\text { Permeability } \\
\text { test }\left(10^{-3} \mu \mathrm{m}^{2}\right)\end{array}$ & $\begin{array}{c}\text { Stress-strain } \\
\text { test }(\mathrm{MPa})\end{array}$ & $\begin{array}{l}\text { Shear } \\
\text { strength } \\
(\mathrm{MPa})\end{array}$ & $\begin{array}{c}\text { Effective } \\
\text { confining } \\
\text { strength } \\
(\mathrm{MPa})\end{array}$ \\
\hline $05 \mathrm{~B}-2 \mathrm{P}-1 \mathrm{~b}$ & 1127 & 58.31 & 1507 & 0.44 & 1.91 & 0 & 0.084 & 0.23 & 0.285 & 0.15 \\
\hline 08C-4P-1a5 & 799 & 17.47 & 1611 & 0.14 & 1.82 & 9.7 & 0.095 & 0.08 & 0.135 & 0.15 \\
\hline $08 \mathrm{C}-4 \mathrm{P}-1 \mathrm{~b}$ & 799 & 17.59 & 1611 & 0.14 & 1.81 & 14.4 & 0.055 & 0.24 & 0.265 & 0.15 \\
\hline $16 \mathrm{D}-13 \mathrm{~A}-1 \mathrm{a} 6 \mathrm{c}$ & 869 & 200.83 & 1842 & 1.6 & 2.15 & 48.2 & - & 0.5 & 1.185 & 1.6 \\
\hline 16D-13A-1a2 & 869 & 201.24 & 1953 & 1.6 & 2.21 & 53 & 0.006 & 1 & 1.619 & 1.6 \\
\hline $16 \mathrm{D}-13 \mathrm{~A}-1 \mathrm{~b}$ & 869 & 201.47 & 2033 & 1.6 & 2.23 & 55.3 & $<0.003$ & 0.75 & 1.553 & 2.3 \\
\hline $16 \mathrm{D}-13 \mathrm{~A}-1 \mathrm{c}$ & 869 & 201.59 & 2015 & 1.6 & 2.23 & 44 & - & 1.15 & 1.493 & 2.3 \\
\hline
\end{tabular}

-: no data.

decreased and the pressure increased with increasing water depth. At a water depth of $\sim 600 \mathrm{~m}$, the coring tool entered the gas hydrate stability zone (Figure 2(a)). After the sediments were sealed in the coring tool, the pressure was main- tained at an almost constant value, but the temperature increased slowly due to warming of the seawater and air during the core retrieval. During the triaxial and permeability tests, the pressure varied between 11 and $19 \mathrm{MPa}$ due to the 


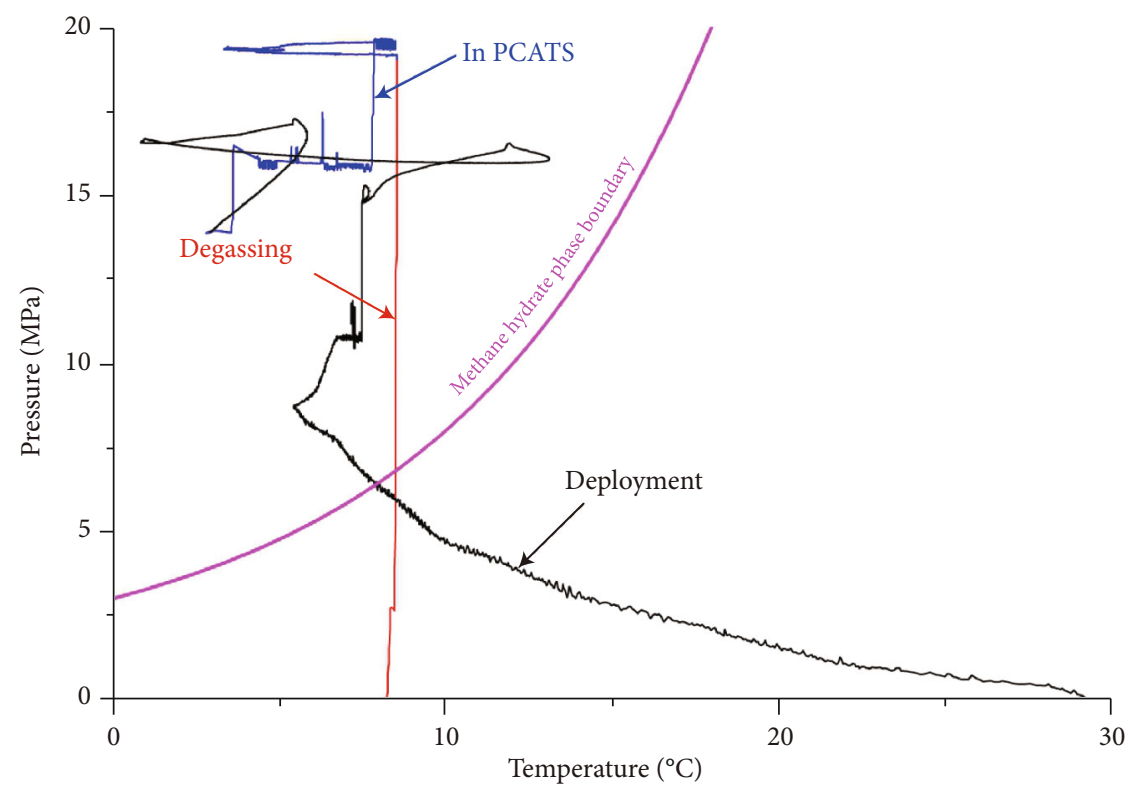

(a)

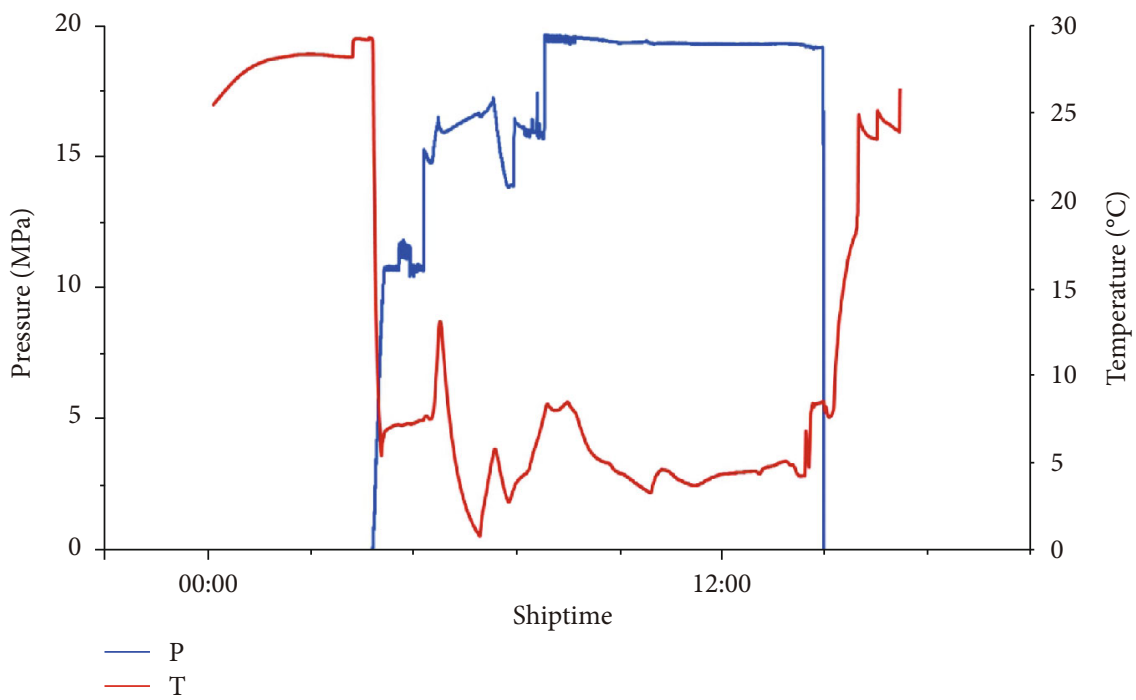

(b)

FiguRE 2: (a) comparison of the pressure and temperature conditions with the gas hydrate phase diagram. Pink line: phase boundary of methane hydrates within a $3.5 \mathrm{wt} \% \mathrm{NaCl}$ solution [8]. Black line: deployment of the pressure coring system, including from the vessel to the seafloor, within the borehole, from the seafloor back to the vessel, and from the deck to the lab. Blue line: within the PCATS for the entire triaxial test. Red line: degassing of the pressure core. (b) Temperature and pressure variations of the core with time.

core operations. The temperature was less than $10^{\circ} \mathrm{C}$ during most of the coring operations (Figure 2(b)). The permeability test was followed by degassing. Although the pressure and temperature varied during the coring operations, based on the phase diagram (Figure 2(a)), the gas hydrates did not decompose.

3.2. MSCL Measurements and Gas Hydrate Saturation. The depressurization of subsample $05 \mathrm{~B}-2 \mathrm{P}-1 \mathrm{~b}$ shows that the methane concentration did not exceed the in situ methane gas saturation in the pore water, indicating that there were no gas hydrates in this subsample. The X-ray image of 05B$2 \mathrm{P}-1 \mathrm{~b}$ shows a homogenous lithology, which is consistent with the observed greyish clay in the core description (Figure 3). The average gamma density was $1.9 \mathrm{~g} / \mathrm{cm}^{3}$, with a variation of less than $0.1 \mathrm{~g} / \mathrm{cm}^{3}$, and the average P-wave velocity $(\mathrm{Vp})$ was $1505 \mathrm{~m} / \mathrm{s}$, with a variation of less than $15 \mathrm{~m} / \mathrm{s}$.

The X-ray image of subsample $08 \mathrm{C}-4 \mathrm{P}-1 \mathrm{~b}$ shows many 1-5 $\mathrm{mm}$ gas hydrate layers and veins (Figure 3 ). The depressurization of $08 \mathrm{C}-4 \mathrm{P}-1 \mathrm{a} 5$ and $08 \mathrm{C}-4 \mathrm{P}-1 \mathrm{~b}$ revealed that their gas hydrate saturations were $9.7 \%$ and $14.4 \%$ of the pore volume, respectively. Their gamma density and $\mathrm{Vp}$ values were almost constant, with average values of $1.8 \mathrm{~g} / \mathrm{cm}^{3}$ and $1610 \mathrm{~m} / \mathrm{s}$, respectively.

Four subsamples of 16D-13A were depressurized. Except for subsample 16D-13A-1a2, which lost methane during 

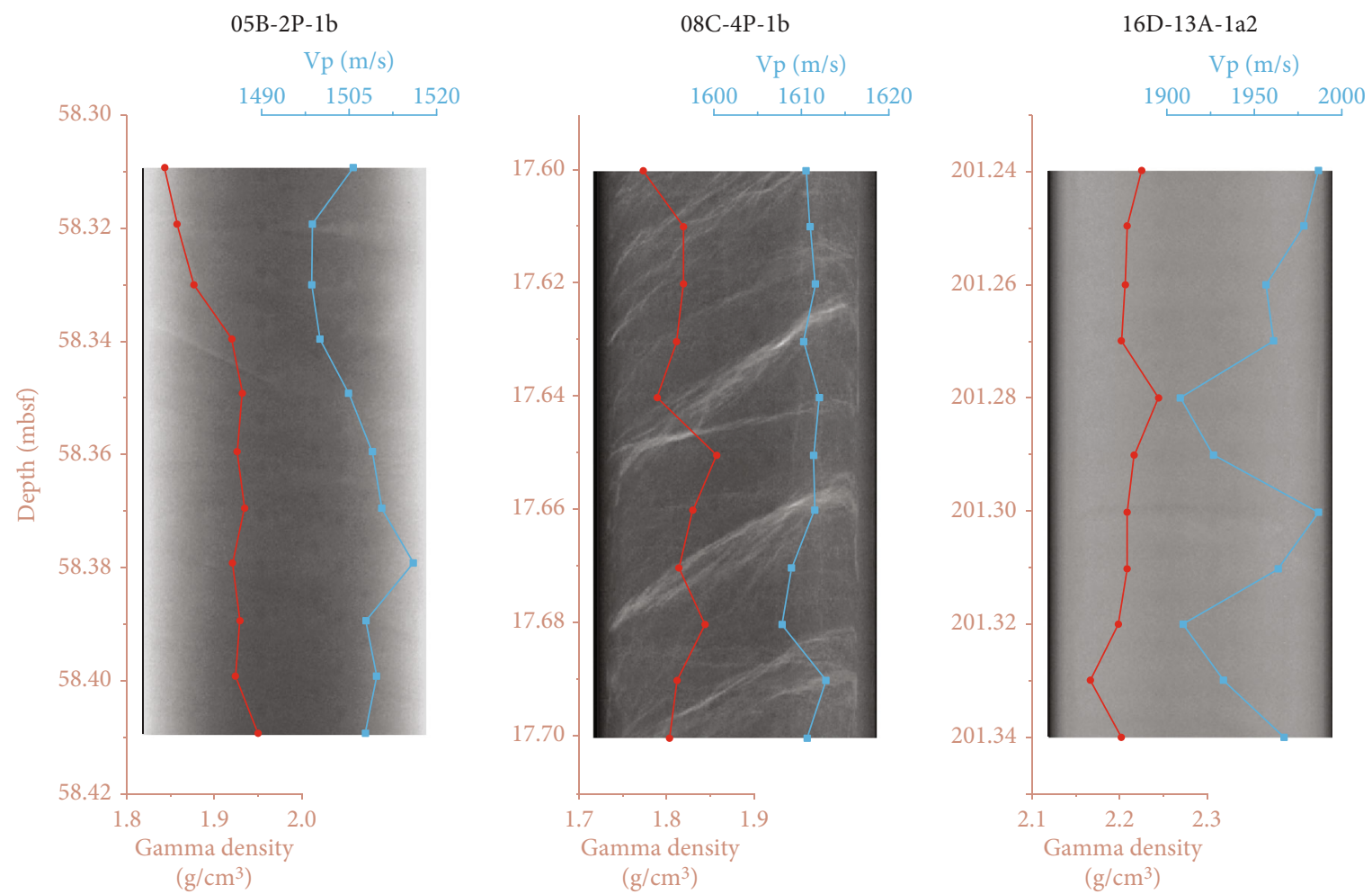

FIgURE 3: Typical gamma density (red dot), P-wave velocity (blue dot), and X-ray images of the subsamples.

depressurization, the gas hydrate saturations of the other three samples were $44 \%-55 \%$ of the pore volume. The Xray image of $16 \mathrm{D}-13 \mathrm{~A}-1 \mathrm{a} 2$ did not show a distinct gas hydrate distribution (e.g., layers and veins); therefore, it is speculated that the gas hydrates may have been finely distributed in the pore space (Figure 3). This core consists of homogenous silty clay with biscuit intervals. The density did not vary significantly; however, the $\mathrm{Vp}$ reached high values of $1700-2050 \mathrm{~m} / \mathrm{s}$.

3.3. Permeability of Gas Hydrate-Bearing Sediments. Permeability tests were conducted on five samples (05B-2P-1b, 08C-4P-1a5, 08C-4P-1b, 16D-13A-1a2, and 16D-13A-1b); all of which were successful, except for 16D-13A-1b. The top and basal pressures recorded over time are shown in Figure 4 . The hydraulic head calculated by multiplying the pressure difference by the pressure constant $(10 \mathrm{kPa} / \mathrm{m})$ ranged from $0.05 \mathrm{~m}$ to $0.08 \mathrm{~m}$. The flow rates of the subsamples ranged from $1.08 \times 10^{-9}$ to $5.79 \times 10^{-11} \mathrm{~m}^{3} / \mathrm{s}$, with a linear fit (Figure 4). The permeabilities of 05B-2P-1b, 08C-4P$1 \mathrm{a} 5$, and $08 \mathrm{C}-4 \mathrm{P}-1 \mathrm{~b}$ were $0.055-0.095 \times 10^{-3} \mu \mathrm{m}^{2}$, while that of $16 \mathrm{D}-13 \mathrm{~A}-1 \mathrm{a} 2$ was only $0.006 \times 10^{-3} \mu \mathrm{m}^{2}$, which is one order of magnitude lower than the others.

3.4. Strength of Gas Hydrate-Bearing Sediments. Triaxial compression strength tests were conducted on each subsample under different effective confining pressures. The peak deviatoric stress was defined as the deviatoric stress at an axial stain of $10 \%$ if the peak value was not reached by the end of the test.
Figure 5 shows the stress-strain curves of the subsamples. Except for 05B-2P-1b, which exhibits slight strain softening, the other six samples exhibit strain hardening, especially subsamples of 16D. Based on the slopes of the initial strain-stress curves, the stiffness of $16 \mathrm{D}-13 \mathrm{~A}$ is much higher than those of $05 \mathrm{~B}-2 \mathrm{P}$ and $08 \mathrm{C}-4 \mathrm{P}$. The peak deviatoric stress of $05 \mathrm{~B}-2 \mathrm{P}-1 \mathrm{~b}$ was $0.285 \mathrm{MPa}$ under an effective confining stress of $0.15 \mathrm{MPa}$. The peak deviatoric stresses of $08 \mathrm{C}-4 \mathrm{P}-1 \mathrm{a} 5$ and $08 \mathrm{C}-4 \mathrm{P}-1 \mathrm{~b}$ were $0.135 \mathrm{MPa}$ and $0.265 \mathrm{MPa}$, respectively, under an effective confining stress of $0.15 \mathrm{MPa}$. Comparative tests were conducted on subsamples of $16 \mathrm{D}$ under various effective confining stresses. The peak deviatoric stresses of 16D-13A-1a6c and 16D-13A1a2 were 1.185 and $1.619 \mathrm{MPa}$, respectively, under an effective confining stress of $1.6 \mathrm{MPa}$, while the values of $16 \mathrm{D}$ $13 \mathrm{~A}-1 \mathrm{~b}$ and $16 \mathrm{D}-13 \mathrm{~A}-1 \mathrm{c}$ were $1.553 \mathrm{MPa}$ and $1.493 \mathrm{MPa}$, respectively, under an effective confining stress of $2.3 \mathrm{MPa}$. It should be noted that some of the curves exhibit sudden decreases in the deviatoric stress; for instance, the deviatoric stress of sample $16 \mathrm{D}-13 \mathrm{~A}-1 \mathrm{~b}$ at an axial strain of $7 \%$ decreased incrementally from $1.40 \mathrm{MPa}$ to $1.05 \mathrm{MPa}$, but it recovered in a short time.

\section{Discussion}

4.1. Gas Hydrate Distribution and Burial Depth. The gas hydrate distribution is controlled by the burial depth [42] and the fluid migration patterns [25, 43-46]. The X-ray images show that the gas hydrates are in the form of veins within the shallow sediments at $\sim 17 \mathrm{~m}$ (08C-4P-1a5 and $08 \mathrm{C}-4 \mathrm{P}-1 \mathrm{~b})$. In the deep sediments, the gas hydrates are 


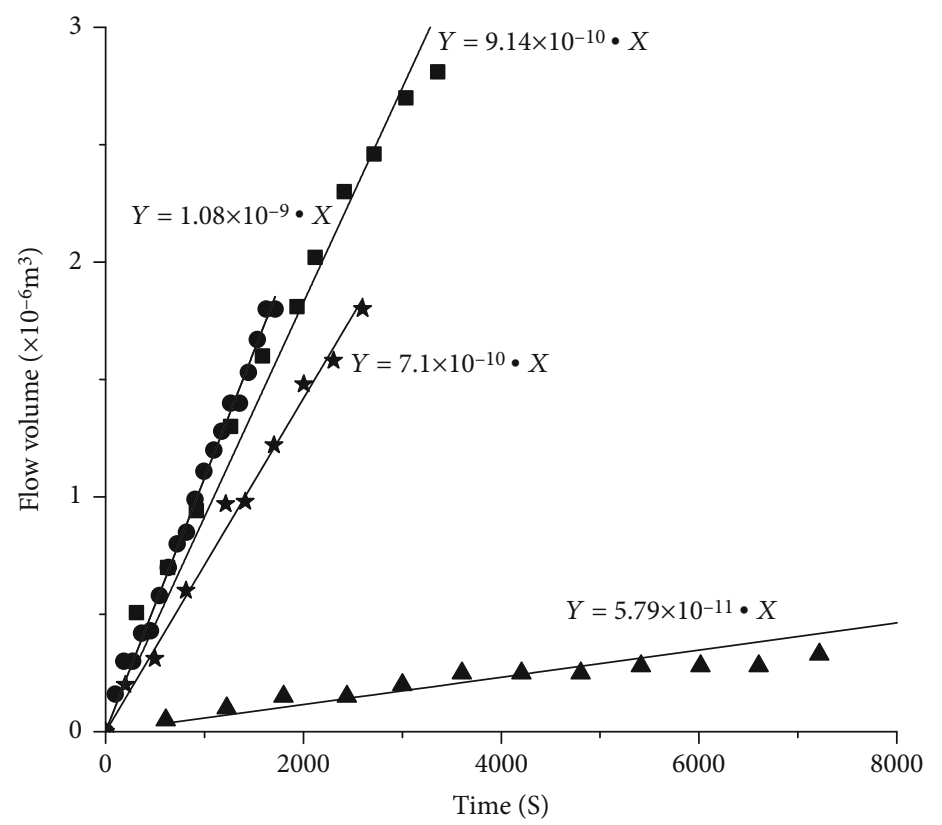
- $08 \mathrm{C}-4 \mathrm{P}-1 \mathrm{a} 5,0.11 \mathrm{MPa}$
A $16 \mathrm{D}-13 \mathrm{~A}-1 \mathrm{a} 2,1.6 \mathrm{MPa}$
$\star 08 \mathrm{C}-4 \mathrm{P}-1 \mathrm{~b}, 0.63 \mathrm{MPa}$
- $05 \mathrm{~B}-2 \mathrm{P}-1 \mathrm{~b}, 0.39 \mathrm{MPa}$

FIgURE 4: Flow volume versus time for the permeability tests.

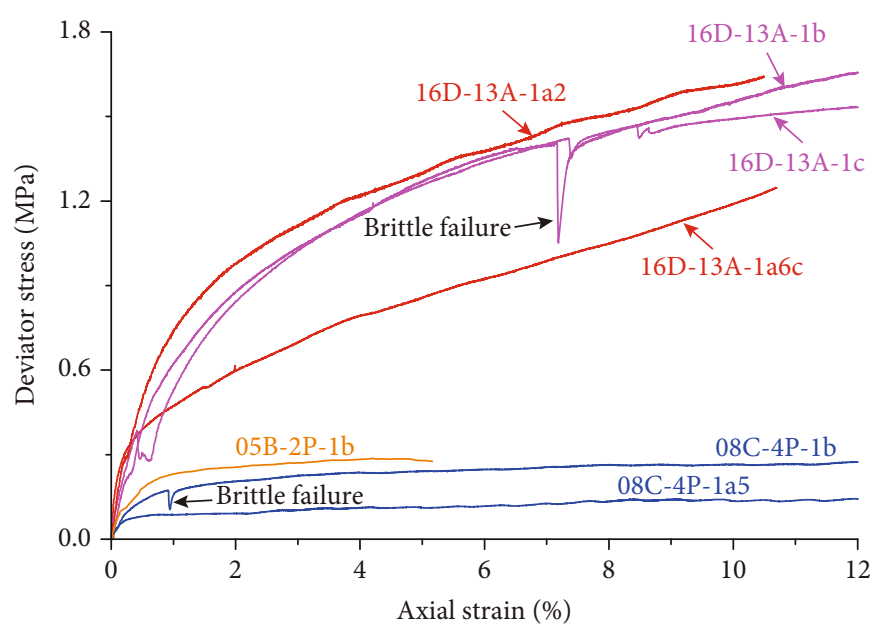

Figure 5: Deviatoric stress versus axial strain during the PCATS triaxial test.

disseminated within the sediments pores (16D-13A, depth $\sim 200 \mathrm{~m}$ ) or fill fractures (16D-13A-1b, depth $\sim 200 \mathrm{~m}$ ). This observation is consistent with the speculation of Dai et al. [43] that the gas hydrate distribution is influenced by the effective stress and the growing space. Within the shallow sediments, gas hydrate nucleation and crystallization can overcome the lithostatic stress and form gas hydrate veins and layers. While in the deep sediments, the gas hydrate growth cannot overcome the lithostatic stress, and thus, they can only form in the pore space and preexisting faults and fractures.

4.2. Factors Controlling the Physical Properties of Gas Hydrate-Bearing Sediments. It has been suggested that the physical properties of gas hydrate-bearing sediments are closely related to the gas hydrate saturation and effective confining stress $[24,26]$. In addition, gas hydrate layers and veins have been discovered in marine sediments in marine sea areas, which can change the marine sediments from isotropic to anisotropic materials $[47,48]$. This inhomogeneity of the material properties increases the difficulty of predicting the stability of the seabed sediments during gas hydrate production [38].

4.2.1. Impact of Gas Hydrate Saturation on the Sediment Strength and Permeability. The permeability of the sediments is influenced by the gas hydrate saturation (Figure 6). Our results show a negative relationship between the permeability 


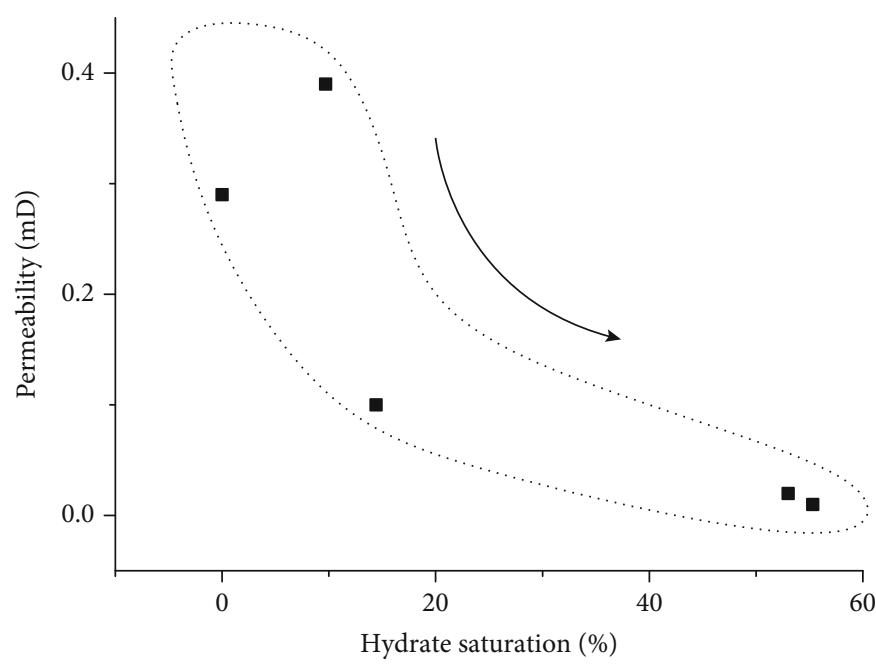

FIGURE 6: Relation between the permeability and hydrate saturation.

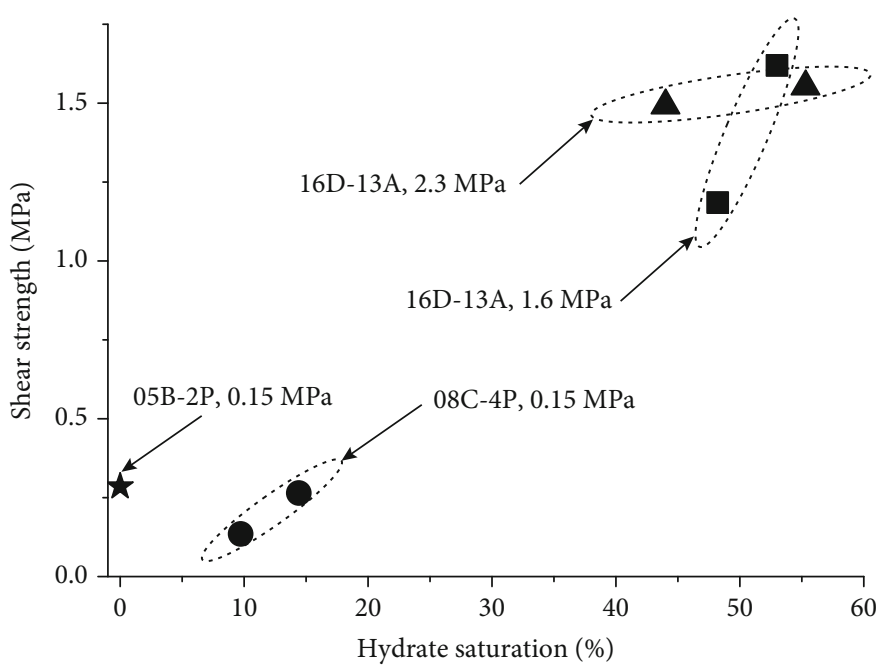

Figure 7: Relationship between the shear strength and hydrate saturation.

and hydrate saturation (Figure 6). When the gas hydrate content increases in the sediments, the pore space is potentially occupied by gas hydrate grains, leading to decrease in the sediment's permeability $[10,14,49]$.

Previous research has revealed that the stiffness and strength of coarse-grained sediments increase with increasing gas hydrate saturation [21, 50, 51]. Waite et al. [52] pointed out that the impact of gas hydrates on the peak deviatoric stress is quite limited when the saturation is less than $30 \%$; however, the impact increases dramatically when the saturation is greater than $40 \%$. Hyodo et al. [11] experimentally determined the exponential relationship between the peak deviatoric stress and gas hydrate saturation. The shear wave velocity did not distinctly increase before the gas hydrate saturation reached $40 \%$, indicating that the effect of gas hydrates on the strength and stiffness of the sediments is not significant below this point. Yoneda et al. [24] pointed out that the effects of gas hydrate saturation are analogies for natural gas hydrates and lab synthetic specimens. In reality, the lab synthetic specimens are more likely to be homogeneous for the gas hydrates formed in the pore spaces of the grains, while gas hydrates in nature are usually more heterogeneous in both pore spaces and the fractures. Therefore, this should be taken into consideration when comparing the effects of the gas hydrate saturation of lab synthetic and natural gas hydrate-bearing sediments.

Figure 7 shows the relationship between gas hydrate saturation and sediment strength. Since subsamples 05B-2P, 08C$2 \mathrm{P}$, and $16 \mathrm{D}-13 \mathrm{~A}$ were subjected to different effective stresses, the influences of the gas hydrate saturation on the strengths of these samples cannot be compared. The eclipses in Figure 7 illustrate three pairs of subsamples, which are from the same burial depth and were subjected to the same effective confining stress during the triaxial tests. The result shows that the stiffness and strength of the sediments increased as the gas hydrate saturation increased. This increase in stiffness is inferred to be caused by the gas hydrates occupying the pore spaces. The gas hydrate cementation between the sediment 


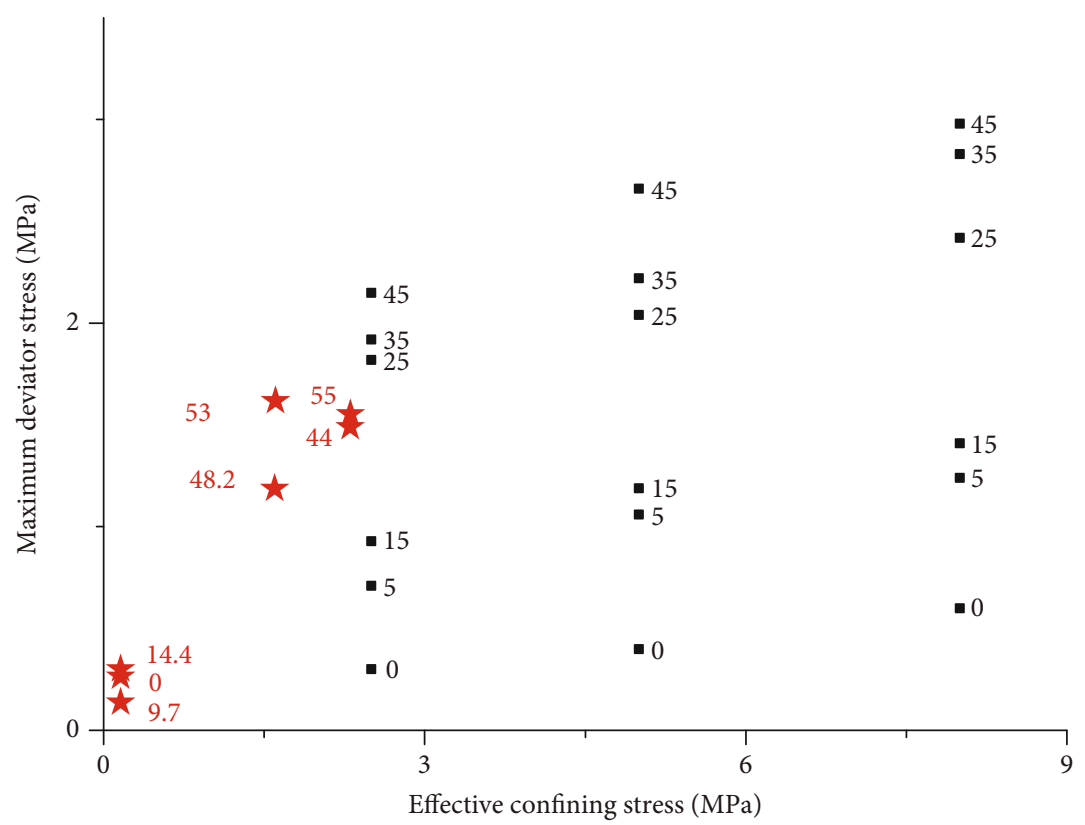

FIGURE 8: Relationship between the effective confining stress and the peak deviatoric stress. Red star: this study. Black box: previous study [17]. The numbers are the gas hydrate saturation within the sediments.

grains resists the rotation, slip, and rearrangement of the grains, which consequently increases the density and strength of the sediments $[17,24]$. This cementation effect increases with increasing gas hydrate saturation.

\subsubsection{Impact of Effective Confining Stress on Sediment} Strength. The sediment stiffness and strength increase as the effective confining stress increases [42, 50, 53]. As is shown in Table 1, the in situ effective stress of subsample 05B-2P-1b (0.44 MPa) is three times higher than the initial effective stress $(0.15 \mathrm{MPa})$, leading to an overconsolidation ratio of $\sim 3$, which is speculated to result in the smallobserved post peak softening behavior during shearing (Figure 5). A highly effective confining stress will increase the effective friction between the sediment grains, and more energy is needed to overcome this friction [50]. The strainstress curve changes from strain softening to strain hardening as the effective confining pressure increases.

Figure 8 illustrates the relationship between the effective confining stress and the strength. It is inferred that the increase in the effective confining stress leads to an increase in the interparticle coordination and the friction between grains, which consequently increase the stiffness and strength of the gas hydrate-bearing sediments.

\section{Conclusions}

In this study, the physical properties of the hydrate-bearing pressure core sediments recovered during the GMGS2 in the South China Sea were analyzed and reported for the first time. The conclusions of this study are as follows:

(1) The gas hydrates within the pressure cores exhibit different morphologies, such as slabs, pore filling, and veins
(2) The gas hydrate distribution is very heterogeneous in the sediments with hydrate saturations of $0 \%-55.3 \%$

(3) The maximum deviatoric strength of the subsamples was $0.135-1.619 \mathrm{MPa}$. The stiffness and strength of the gas hydrate-bearing sediments increase as the gas hydrate saturation and effective confining stress increase

(4) The permeability of the subsamples ranged from $0.006 \times 10^{-3} \mu \mathrm{m}^{2}$ to $0.095 \times 10^{-3} \mu \mathrm{m}^{2}$, and the permeability is negatively correlated with hydrate saturation

\section{Data Availability}

The data used to support the findings of this study are available from the corresponding author upon request.

\section{Conflicts of Interest}

The authors declare that they have no conflicts of interest.

\section{Acknowledgments}

This research was supported by the Key Special Project for Introducing Talent Teams of the Southern Marine Science and Engineering Guangdong Laboratory (Guangzhou) (no. GML2019ZD0201), the National Key Research and Development Plan (no. 2018YFC0310000), the Key Laboratory of Marine Mineral Resources, Ministry of Land and Resources (no. KLMMR-2015-A-07), the China Geological Survey Project (nos. DD20160227 and DD20160227-05), and the National Natural Science Foundation of China (no. U1806230). 


\section{References}

[1] S. Dai, J.-H. Cha, E. J. Rosenbaum, W. Zhang, and Y. Seol, "Thermal conductivity measurements in unsaturated hydrate-bearing sediments," Geophysical Research Letters, vol. 42, no. 15, pp. 6295-6305, 2015.

[2] S. Dai, J. Y. Lee, and J. C. Santamarina, "Hydrate nucleation in quiescent and dynamic conditions," Fluid Phase Equilibria, vol. 378, pp. 107-112, 2014.

[3] T. Pape, A. Bahr, S. A. Klapp, F. Abegg, and G. Bohrmann, "High-intensity gas seepage causes rafting of shallow gas hydrates in the southeastern Black Sea," Earth and Planetary Science Letters, vol. 307, no. 1-2, pp. 35-46, 2011.

[4] C. Ruppel, R. Boswell, and E. Jones, "Scientific results from Gulf of Mexico Gas Hydrates Joint Industry Project Leg 1 drilling: introduction and overview," Marine and Petroleum Geology, vol. 25, no. 9, pp. 819-829, 2008.

[5] M. E. Torres, A. M. Tréhu, N. Cespedes et al., "Methane hydrate formation in turbidite sediments of northern Cascadia, IODP Expedition 311," Earth and Planetary Science Letters, vol. 271, no. 1-4, pp. 170-180, 2008.

[6] T. S. Collett, R. E. Lewis, W. J. Winters, M. W. Lee, K. K. Rose, and R. M. Boswell, "Downhole well log and core montages from the Mount Elbert Gas Hydrate Stratigraphic Test Well, Alaska North Slope," Marine and Petroleum Geology, vol. 28, no. 2, pp. 561-577, 2011.

[7] S. Dai, C. Lee, and J. Carlos Santamarina, "Formation history and physical properties of sediments from the Mount Elbert Gas Hydrate Stratigraphic Test Well, Alaska North Slope," Marine and Petroleum Geology, vol. 28, no. 2, pp. 427-438, 2011.

[8] T. Pape, T. Feseker, S. Kasten, D. Fischer, and G. Bohrmann, "Distribution and abundance of gas hydrates in near-surface deposits of the Håkon Mosby Mud Volcano, SW Barents Sea," Geochemistry, Geophysics, Geosystems, vol. 12, no. 9, article Q09009, 2011.

[9] Z. Sha, J. Liang, G. Zhang et al., "A seepage gas hydrate system in northern South China Sea: seismic and well log interpretations," Marine Geology, vol. 366, pp. 69-78, 2015.

[10] S. Dai and Y. Seol, "Water permeability in hydrate-bearing sediments: a pore-scale study," Geophysical Research Letters, vol. 41, no. 12, pp. 4176-4184, 2014.

[11] M. Hyodo, Y. Li, J. Yoneda et al., "Mechanical behavior of gassaturated methane hydrate-bearing sediments," Journal of Geophysical Research: Solid Earth, vol. 118, no. 10, pp. 51855194, 2013.

[12] K. Miyazaki, A. Masui, Y. Sakamoto, K. Aoki, N. Tenma, and T. Yamaguchi, "Triaxial compressive properties of artificial methane-hydrate-bearing sediment," Journal of Geophysical Research Solid Earth, vol. 116, no. B6, article B06102, 2011.

[13] J. A. Priest, A. I. Best, and C. R. I. Clayton, "A laboratory investigation into the seismic velocities of methane gas hydratebearing sand," Journal of Geophysical Research Solid Earth, vol. 110, article B04102, 2005.

[14] Y. Seol and T. J. Kneafsey, "Methane hydrate induced permeability modification for multiphase flow in unsaturated porous media," Journal of Geophysical Research: Solid Earth, vol. 116, article B08102, 2011.

[15] M. Hyodo, J. Yoneda, N. Yoshimoto, and Y. Nakata, "Mechanical and dissociation properties of methane hydrate-bearing sand in deep seabed," Soils \& Foundations, vol. 53, no. 2, pp. 299-314, 2013.
[16] N. Sultan, P. Cochonat, J. P. Foucher, and J. Mienert, "Effect of gas hydrates melting on seafloor slope instability," Marine Geology, vol. 213, no. 1-4, pp. 379-401, 2004.

[17] X. H. Zhang and X. B. Lu, "Initiation and expansion of layered fracture in sediments due to thermal-induced hydrate dissociation," Journal of Petroleum Science and Engineering, vol. 133, pp. 881-888, 2015.

[18] K. Yamamoto, T. Kanno, X. X. Wang et al., "Thermal responses of a gas hydrate-bearing sediment to a depressurization operation," RSC Advances, vol. 7, no. 10, pp. 5554-5577, 2017.

[19] R. L. Kleinberg, C. Flaum, D. D. Griffin et al., "Deep sea NMR: methane hydrate growth habit in porous media and its relationship to hydraulic permeability, deposit accumulation, and submarine slope stability," Journal of Geophysical Research: Solid Earth, vol. 108, no. B10, p. 2508, 2003.

[20] T. S. Yun, J. C. Santamarina, and C. Ruppel, "Mechanical properties of sand, silt, and clay containing tetrahydrofuran hydrate," Journal of Geophysical Research: Solid Earth, vol. 112, no. B4, article B04106, 2007.

[21] X. H. Zhang, X. B. Lu, Y. H. Shi, and Z. Xia, "Study on the mechanical properties of hydrate-bearing silty clay," Marine and Petroleum Geology, vol. 67, pp. 72-80, 2015.

[22] J. A. Priest, M. Druce, J. Roberts, P. Schultheiss, Y. Nakatsuka, and K. Suzuki, "PCATS Triaxial: a new geotechnical apparatus for characterizing pressure cores from the Nankai Trough, Japan," Marine and Petroleum Geology, vol. 66, Part 2, pp. 460-470, 2015.

[23] J. C. Santamarina, S. Dai, M. Terzariol et al., "Hydro-bio-geomechanical properties of hydrate-bearing sediments from Nankai Trough," Marine and Petroleum Geology, vol. 66, Part 2, pp. 434-450, 2015.

[24] J. Yoneda, A. Masui, Y. Konno et al., "Mechanical properties of hydrate-bearing turbidite reservoir in the first gas production test site of the Eastern Nankai Trough," Marine and Petroleum Geology, vol. 66, Part 2, pp. 471-486, 2015.

[25] G. Bohrmann, W. F. Kuhs, S. A. Klapp et al., “Appearance and preservation of natural gas hydrate from hydrate ridge sampled during ODP Leg 204 drilling," Marine Geology, vol. 244, no. 1-4, pp. 1-14, 2007.

[26] J. Yoneda, A. Masui, Y. Konno et al., "Pressure-core-based reservoir characterization for geomechanics: insights from gas hydrate drilling during 2012-2013 at the eastern Nankai trough," Marine and Petroleum Geology, vol. 86, pp. 1-16, 2017.

[27] T. S. Collett, R. Boswell, J. R. Cochran et al., "Geologic implications of gas hydrates in the offshore of India: results of the National Gas Hydrate Program Expedition 01," Marine and Petroleum Geology, vol. 58, no. Part A, pp. 3-28, 2014.

[28] N. Inada and K. Yamamoto, "Data report: Hybrid Pressure Coring System tool review and summary of recovery result from gas-hydrate related coring in the Nankai Project," Marine and Petroleum Geology, vol. 66, Part 2, pp. 323-345, 2015.

[29] T. S. Yun, C. Lee, J. S. Lee, J. J. Bahk, and J. C. Santamarina, “A pressure core based characterization of hydrate-bearing sediments in the Ulleung Basin, Sea of Japan (East Sea)," Journal of Geophysical Research, vol. 116, no. B2, 2011.

[30] J. Y. Lee, J. W. Jung, M. H. Lee et al., "Pressure core based study of gas hydrates in the Ulleung Basin and implication for geomechanical controls on gas hydrate occurrence," Marine and Petroleum Geology, vol. 47, pp. 85-98, 2013. 
[31] J. Liang, W. Zhang, J. A. Lu, J. Wei, Z. Kuang, and Y. He, "Geological occurrence and accumulation mechanism of natural gas hydrates in the eastern Qiongdongnan Basin of the South China Sea: insights from site GMGS5-W9-2018," Marine Geology, vol. 418, article 106042, 2019.

[32] J. Wei, Y. Fang, H. Lu et al., "Distribution and characteristics of natural gas hydrates in the Shenhu Sea area, South China Sea," Marine and Petroleum Geology, vol. 98, pp. 622-628, 2018.

[33] J. Wei, J. Liang, J. Lu, W. Zhang, and Y. He, "Characteristics and dynamics of gas hydrate systems in the northwestern South China Sea - results of the fifth gas hydrate drilling expedition," Marine and Petroleum Geology, vol. 110, pp. 287-298, 2019.

[34] J. Ye, J. Wei, J. Liang, J. Lu, H. Lu, and W. Zhang, "Complex gas hydrate system in a gas chimney, South China Sea," Marine and Petroleum Geology, vol. 104, pp. 29-39, 2019.

[35] W. Zhang, J. Liang, J.'a. Lu et al., “Accumulation features and mechanisms of high saturation natural gas hydrate in Shenhu area, northern South China Sea," Petroleum Exploration and Development, vol. 44, no. 5, pp. 708-719, 2017.

[36] W. Zhang, J. Liang, J. Wei et al., "Geological and geophysical features of and controls on occurrence and accumulation of gas hydrates in the first offshore gas-hydrate production test region in the Shenhu area, Northern South China Sea," Marine and Petroleum Geology, vol. 114, article 104191, 2020.

[37] W. Zhang, J. Liang, J. Wei, P. Su, L. Lin, and W. Huang, "Origin of natural gases and associated gas hydrates in the Shenhu area, northern South China Sea: results from the China gas hydrate drilling expeditions," Journal of Asian Earth Sciences, vol. 183, p. 103953, 2019.

[38] J. Ye, X. Qin, H. Qiu et al., "Preliminary results of environmental monitoring of the natural gas hydrate production test in the South China Sea," China Geology, vol. 1, no. 2, pp. 202-209, 2018.

[39] G. Zhang, J. Liang, J. A. Lu et al., "Geological features, controlling factors and potential prospects of the gas hydrate occurrence in the east part of the Pearl River Mouth Basin, South China Sea," Marine and Petroleum Geology, vol. 67, pp. 356367, 2015.

[40] J. Kestin, M. Sokolov, and W. A. Wakeham, "Viscosity of liquid water in the range $-8{ }^{\circ} \mathrm{C}$ to $150^{\circ} \mathrm{C}$," Journal of Physical and Chemical Reference Data, vol. 7, no. 3, pp. 941-948, 1978.

[41] W. Xu, "Modeling dynamic marine gas hydrate systems," American Mineralogist, vol. 89, no. 8-9, pp. 1271-1279, 2004.

[42] J. A. Priest, C. R. I. Clayton, and E. V. L. Rees, "Potential impact of gas hydrate and its dissociation on the strength of host sediment in the Krishna-Godavari Basin," Marine and Petroleum Geology, vol. 58, no. Part A, pp. 187-198, 2014.

[43] S. Dai, J. C. Santamarina, W. F. Waite, and T. J. Kneafsey, "Hydrate morphology: physical properties of sands with patchy hydrate saturation," Journal of Geophysical Research: Solid Earth, vol. 117, no. B11, article B11205, 2012.

[44] M. E. Torres, J. McManus, D. E. Hammond et al., "Fluid and chemical fluxes in and out of sediments hosting methane hydrate deposits on hydrate ridge, OR, I: hydrological provinces," Earth and Planetary Science Letters, vol. 201, no. 3-4, pp. 525-540, 2002.

[45] J. Wei, T. Wu, W. Zhang et al., "Deeply buried Authigenic carbonates in the Qiongdongnan Basin, South China Sea: implications for ancient cold seep activities," Minerals, vol. 10, no. 12 , p. $1135,2020$.
[46] T. Wu, X. Deng, H. Yao et al., "Distribution and development of submarine mud volcanoes on the Makran Continental Margin, offshore Pakistan," Journal of Asian Earth Sciences, vol. 207, p. 104653, 2021.

[47] J. Wei, J. Li, T. Wu et al., "Geologically controlled intermittent gas eruption and its impact on bottom water temperature and chemosynthetic communities-a case study in the "HaiMa" cold seeps, South China Sea," Geological Journal, vol. 55, no. 9, pp. 6066-6078, 2020.

[48] J. Wei, T. Pape, N. Sultan et al., "Gas hydrate distributions in sediments of pockmarks from the Nigerian margin - results and interpretation from shallow drilling," Marine and Petroleum Geology, vol. 59, pp. 359-370, 2015.

[49] J. Nimblett and C. Ruppel, "Permeability evolution during the formation of gas hydrates in marine sediments," Journal of Geophysical Research: Solid Earth, vol. 108, no. B9, p. 2420, 2003.

[50] M. Hyodo, Y. Li, J. Yoneda et al., "A comparative analysis of the mechanical behavior of carbon dioxide and methane hydrate-bearing sediments," American Mineralogist, vol. 99, no. 1, pp. 178-183, 2014.

[51] J. Yoneda, A. Masui, Y. Konno et al., "Mechanical behavior of hydrate-bearing pressure-core sediments visualized under triaxial compression," Marine and Petroleum Geology, vol. 66, Part 2, pp. 451-459, 2015.

[52] W. F. Waite, J. C. Santamarina, D. D. Cortes et al., "Physical properties of hydrate-bearing sediments," Reviews of Geophysics, vol. 47, article RG4003, 2009.

[53] Y. Song, F. Yu, Y. Li, W. Liu, and J. Zhao, "Mechanical property of artificial methane hydrate under triaxial compression," Journal of Natural Gas Chemistry, vol. 19, no. 3, pp. 246-250, 2010. 